\title{
QUARTERLY OUTLOOK ON \\ MONETARY, BANKING, AND PAYMENT SYSTEM IN INDONESIA: QUARTER II, 2016
}

\author{
TM. Arief Machmud, Syachman Perdymer, Muslimin Anwar, \\ Nurkholisoh Ibnu Aman, Tri Kurnia Ayu K, \\ Anggita Cinditya Mutiara K, Illinia Ayudhia Riyadi'
}

\begin{abstract}
The growth of Indonesian economy on Quarter II, 2016 increased with a well-maintained financial system and macroeconomic stability. Though the growth was not uniform across sectors, the aggregate growth has increased during this quarter, supported by domestic demand, fiscal stimulus, along with monetary policy ease. On the other hand, the macroeconomic stability was well preserved as reflected on inflation within the band target, a better current account deficit, and relatively stable Rupiah's rate. This stable macroeconomic condition enabled the monetary authority to ease their policy. In the future, the policy coordination between the fiscal and the monetary authority is required, particularly on accelerating the implementation of structural reform, to support a sustainable economic growth.
\end{abstract}

Keywords: macroeconomy, monetary, economic outlook, Indonesia.

JEL Classification: C53, E66, F01, F41

1 Authors are researcher on Monetary and Economic Policy Department (DKEM). TM_Arief Machmud (tm arief@bi.go.id); Syachman Perdymer (syachman@bi.go.id); Muslimin AAnwar (imus@bi.go.id); Nurkholisoh Ibnu Aman (nurkholisoh@bi.go.id); Tri Kurnia Ayu K (tri kas@bi.go.id); Anggita Cinditya Mutiara K (anggita cmk@bi.go.id); Illinia Ayudhia Riyadi (illinia ar@bi.go.id). 


\section{PERKEMBANGAN GLOBAL}

Pertumbuhan ekonomi global diperkirakan masih belum menguat. Meskipun membaik akibat peningkatan konsumsi dan perbaikan sektor tenaga kerja, ekonomi AS pada triwulan II 2016 tumbuh di bawah perkiraan seiring dengan investasi yang masih melambat. Perkembangan ekonomi AS tersebut masih dibayangi oleh ketidakpastian, sehingga kenaikan Fed Fund Rate (FFR) pada 2016 diperkirakan akan dilakukan hanya satu kali dalam 2016. Sementara itu, ekonomi Eropa diperkirakan tumbuh moderat, dibayangi oleh ketidakpastian pasca Brexit. Demikian pula ekonomi Tiongkok diperkirakan masih tumbuh terbatas karena investasi publik belum dapat memberikan dorongan pada sektor swasta yang masih menghadapi overcapacity dan tingginya utang korporasi. Di sisi lain, di pasar komoditas, harga minyak dunia mulai meningkat meskipun masih rendah. Harga beberapa komoditas ekspor Indonesia juga membaik, seperti CPO, batubara, dan timah.

Ekonomi AS pada triwulan II 2016 tumbuh di bawah perkiraan seiring dengan investasi yang masih melambat. Produk Domestrik Bruto (PDB) AS pada triwulan II 2016 tumbuh sebesar $1,2 \%$, di bawah nowcasts $(1,8-2,9 \%)$ dan pertumbuhan tahun lalu (Grafik 1). Pertumbuhan ekonomi AS yang berada di bawah perkiraan tersebut dipengaruhi oleh investasi yang masih melambat, baik investasi residensial maupun nonresidensial (Grafik 2). Kondisi ini terjadi antara lain akibat ketidakpastian yang meningkat dan kontraksi inventory. Meskipun demikian, ekonomi AS membaik dari triwulan sebelumnya akibat peningkatan konsumsi. Konsumsi AS pada triwulan II 2016 naik signifikan terutama didorong goods consumption. Meningkatnya konsumsi AS tercermin pada pertumbuhan konsumsi PCE kuartal II 2016 yang tercatat tertinggi sejak 2014, yaitu sebesar 4,2\% (SAAR). Selain itu, sektor tenaga kerja juga membaik, tercermin dari meningkatnya penyerapan tenaga kerja (nonfarm payroll) yang lebih tinggi dari rata-rata historis 5 tahun terakhir yang disertai dengan peningkatan upah nominal.

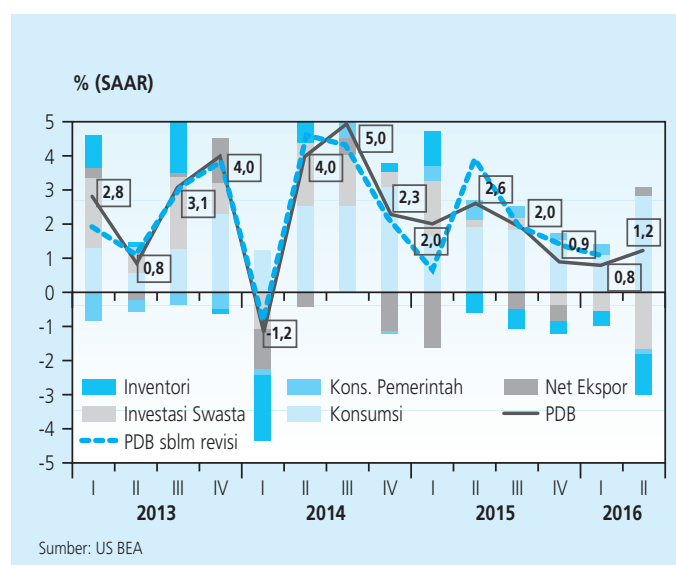

Grafik 1. Kontribusi Pertumbuhan PDB AS

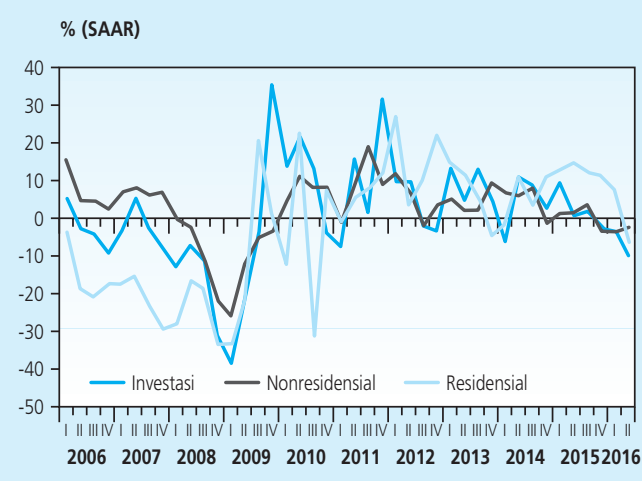

Grafik 2. Pertumbuhan Investasi AS 
Perkembangan ekonomi AS masih dibayangi oleh ketidakpastian, sehingga kenaikan Fed Fund Rate (FFR) pada 2016 diperkirakan akan dilakukan hanya satu kali dalam 2016. Ketidakpastian yang masih tinggi, antara lain, didorong oleh volatilitas pasar keuangan pasca Brexit.

Sementara itu, ekonomi Eropa diperkirakan tumbuh moderat, dibayangi oleh ketidakpastian pasca Brexit. Konsumsi cenderung masih lemah sejalan dengan penurunan retail sales dan berkurangnya pertumbuhan kredit konsumsi (Grafik 3). Dari sisi sektoral, sektor industri, manufaktur, dan konstruksi terindikasi melambat, meski sempat menguat pada triwulan I 2016. Di sisi lain, CPI pada bulan Juni 2016 diumumkan sebesar 0,1\% (yoy) atau 0,2\% (MoM), dipengaruhi oleh penurunan harga energi yang tidak sedalam sebelumnya. Sementara itu, ketidakpastian pasca Brexit terus berlanjut dan berdampak pada menurunnya keyakinan pelaku pasar. Hal ini tercermin dari penurunan Sentix Investor Confidence menjadi 1,72 (sebelumnya 9,9) dan Zew Survey Expectation yang turun menjadi -14,7 (sebelumnya 20,2), terendah sejak 2012.

Perekonomian Tiongkok diperkirakan masih tumbuh terbatas. Hal ini disebabkan karena investasi publik belum dapat memberikan dorongan pada sektor swasta yang masih menghadapi overcapacity dan tingginya utang korporasi. Deselerasi investasi swasta terus berlanjut meskipun suku bunga dipertahankan rendah. Lemahnya pengeluaran swasta tersebut dikompensasi dengan pengeluaran sektor publik (Grafik 4). Sementara itu, rebalancing ekonomi menjadi consumption-led driven berjalan lambat, seiring dengan retail sales yang masih di sekitar level terendah.

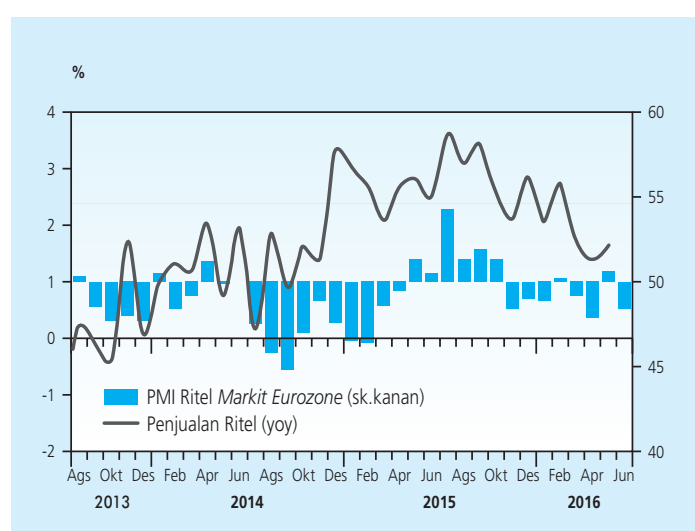

Grafik 3.

Retail Sales dan Market Retail PMI Eropa

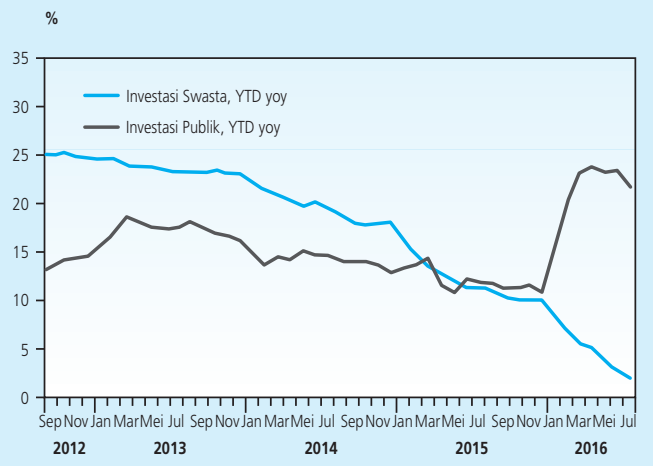

Grafik 4.

Investasi Publik dan Swasta Tiongkok

Di komoditas, harga minyak dunia mulai meningkat meskipun masih rendah (Grafik 5). Gangguan supply sejumlah negara dan turunnya produksi AS masih mendorong kenaikan 
harga. Gangguan produksi minyak sebagian besar berasal dari Libya, Nigeria, dan Kanada. Gangguan tersebut mempercepat kenaikan harga minyak dunia selama beberapa bulan terakhir. Menurunnya produksi minyak AS disebabkan oleh tingkat investasi yang rendah pada tahun 2015, sementara depletion rate pengeboran AS relatif tinggi (2-3 tahun). Sementara itu, harga beberapa komoditas ekspor Indonesia juga membaik, seperti CPO, batubara, dan timah. Harga CPO naik karena penurunan produksi, tercermin dari inventory CPO Malaysia yang terus turun hingga berada di bawah level historis. Pemotongan produksi batubara Tiongkok lebih besar dari penurunan permintaan dunia sehingga membantu kenaikan harga batubara. Selain itu, harga timah naik karena turunnya inventory.

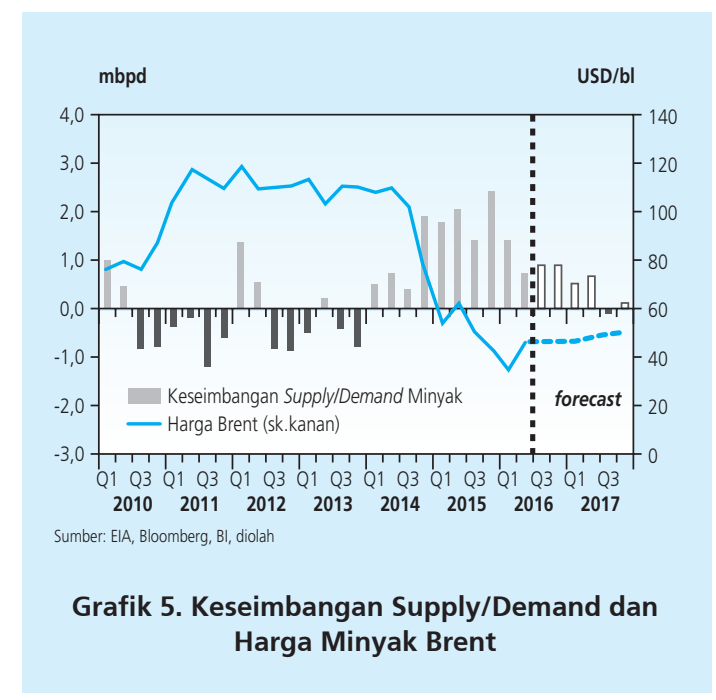

\section{DINAMIKA MAKROEKONOMI INDONESIA}

\subsection{Pertumbuhan Ekonomi}

Pertumbuhan ekonomi Indonesia meningkat pada triwulan II 2016, meskipun belum merata baik secara spasial maupun sektoral. Pertumbuhan ekonomi pada triwulan II 2016 mencapai 5,18\% (yoy), lebih tinggi dibandingkan triwulan sebelumnya sebesar 4,91\% (yoy). Meningkatnya kinerja ekonomi pada triwulan II 2016 didorong oleh meningkatnya permintaan domestik, terutama konsumsi dan investasi pemerintah serta konsumsi rumah tangga. Stimulus fiskal dan kebijakan moneter yang longgar mulai memberi daya dorong terhadap konsumsi pemerintah dan konsumsi swasta (Tabel 1). 


\begin{tabular}{|c|c|c|c|c|c|c|c|c|}
\hline \multicolumn{9}{|c|}{$\begin{array}{c}\text { Tabel } 1 \\
\text { Pertumbuhan Ekonomi Sisi Pengeluaran (\%,yoy) }\end{array}$} \\
\hline \multirow{2}{*}{ Komponen } & \multirow{2}{*}{2014} & \multicolumn{4}{|c|}{2015} & \multirow{2}{*}{2015} & \multicolumn{2}{|c|}{2016} \\
\hline & & I & II & III & IV & & $\mathrm{I}$ & II \\
\hline Konsumsi Rumah Tangga & 5,16 & 5,01 & 4,97 & 4,95 & 4,92 & 4,96 & 4,94 & 5,04 \\
\hline Konsumsi LNPRT & 12,19 & $-8,07$ & $-7,99$ & 6,56 & 8,32 & $-0,63$ & 6,40 & 6,72 \\
\hline Konsumsi Pemerintah & 1,16 & 2,91 & 2,61 & 7,11 & 7,31 & 5,38 & 2,94 & 6,28 \\
\hline Investasi & 4,57 & 4,63 & 3,88 & 4,79 & 6,90 & 5,07 & 5,57 & 5,06 \\
\hline Investasi Bangunan & 5,52 & 5,47 & 4,82 & 6,25 & 8,21 & 6,23 & 7,67 & 6,14 \\
\hline Investasi Non Bangunan & 2,03 & 2,35 & 1,32 & 0,73 & 3,10 & 1,87 & $-0,28$ & 2,02 \\
\hline Ekspor Barang dan Jasa & 1,00 & $-0,62$ & $-0,01$ & $-0,60$ & $-6,44$ & $-1,97$ & $-3,53$ & $-2,73$ \\
\hline Impor Barang dan Jasa & 2,19 & $-2,19$ & $-6,97$ & $-5,90$ & $-8,05$ & $-5,84$ & $-5,08$ & $-3,01$ \\
\hline PDB & 5,02 & 4,73 & 4,66 & 4,74 & 5,04 & 4,79 & 4,91 & 5,18 \\
\hline
\end{tabular}

Konsumsi pemerintah meningkat, sejalan dengan berlanjutnya stimulus fiskal. Konsumsi pemerintah naik dari 2,94\% (yoy) pada triwulan I 2016 menjadi 6,28\% (yoy). Kenaikan tersebut dipengaruhi oleh akselerasi belanja pemerintah, dengan peningkatan belanja pegawai dan belanja barang yang signifikan. Selain karena akselerasi yang terus berlanjut, peningkatan pertumbuhan konsumsi pemerintah juga terjadi karena base effect akibat kendala perubahan nomenklatur yang baru tertangani menjelang akhir triwulan II 2015.

Selain konsumsi pemerintah, konsumsi rumah tangga menjadi pendorong meningkatnya pertumbuhan ekonomi pada triwulan II 2016. Hal ini tercermin dari pertumbuhan konsumsi rumah tangga yang naik dari 4,94\% (yoy) pada triwulan I 2016 menjadi 5,04\% (yoy). Meningkatnya konsumsi rumah tangga tersebut terjadi pada kelompok makanan dan nonmakanan. Efek multiplier fiskal dan kebijakan moneter yang akomodatif mulai memberikan daya dorong terhadap konsumsi rumah tangga. Konsumsi rumah tangga yang masih kuat didukung oleh sejumlah indikator konsumsi yang menunjukkan perkembangan positif. Penjualan eceran mengalami kenaikan yang bersumber dari perbaikan penjualan semua kelompok komoditas, dengan pertumbuhan tertinggi dari kelompok peralatan informasi dan komunikasi (Grafik 6). Sejalan dengan positifnya penjualan eceran, meningkatnya penjualan mobil berlanjut pada triwulan II 2016. Hal ini sesuai dengan pola musiman menjelang perayaan Hari Raya Idul Fitri. Selain itu, Indeks Keyakinan Konsumen (IKK) pada triwulan II 2016 juga menunjukkan peningkatan.

Pertumbuhan investasi melambat, di tengah akselerasi belanja modal Pemerintah. Investasi tumbuh 5,06\% (yoy) pada triwulan II 2016, lebih rendah dibandingkan dengan triwulan sebelumnya yang tumbuh $5,57 \%$ (yoy). Perlambatan tersebut terutama didorong oleh melambatnya investasi bangunan, akibat masih lemahnya minat investasi swasta. Sementara itu, belanja modal pemerintah yang terkait dengan proyek-proyek infrastruktur 
mencatat peningkatan yang cukup signifikan. Perlambatan investasi bangunan tercermin dari penjualan semen yang kembali menurun (Grafik 7). Sementara itu, meskipun belum kuat, investasi nonbangunan telah tumbuh positif (2,02\%, yoy) dibandingkan pertumbuhan triwulan sebelumnya yang mengalami kontraksi (-0,28\%, yoy). Perbaikan investasi nonbangunan terutama didorong oleh tingginya pertumbuhan Cultivated Bioligical Resources (CBR) dan perbaikan investasi mesin dan perlengkapan dan kendaraan, meskipun masih belum solid.

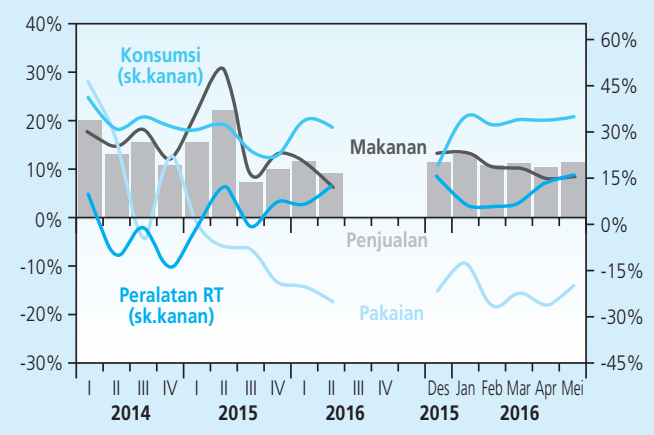

Grafik 6.

Penjualan Eceran

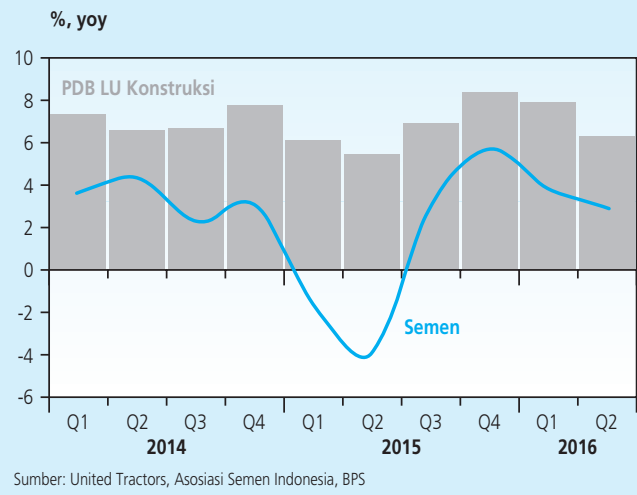

Grafik 7. Penjualan Semen

Dari sisi eksternal, kinerja ekspor menunjukkan perbaikan, meskipun masih terkontraksi, antara lain didukung oleh ekspor beberapa komoditas yang mulai membaik. Ekspor pada triwulan II 2016 mencatat kontraksi 2,73\% (yoy), membaik dibandingkan kontraksi pada triwulan sebelumnya sebesar 3,53\% (yoy). Perbaikan ekspor nonmigas ditopang oleh perbaikan ekspor produk pertanian dan produk manufaktur. Ekspor pertanian pada Juni 2016 tumbuh membaik dibandingkan bulan sebelumnya, ditopang oleh perbaikan ekspor udang dan ikan, rempah-rempah serta teh. Pada Juni 2016, eksor manufaktur juga membaik didorong oleh ekspor TPT, kayu olahan, serta produk kimia. Pebaikan kinerja ekspor manufaktur sejalan dengan positifnya pertumbuhan ekspor Indonesia ke Amerika Serikat pada Juni 2016, yang sebagian besar merupakan ekspor produk manufaktur.

Sejalan dengan peningkatan permintaan domestik, kontraksi impor membaik pada triwulan II 2016. Kontraksi impor membaik pada triwulan II 2016 menjadi 3,01\% (yoy) dari 5,08\% (yoy) pada triwulan I 2016. Tertahannya kontraksi impor terutama ditopang oleh pertumbuhan impor bahan baku dan barang konsumsi. Pertumbuhan impor bahan baku terus meningkat didorong oleh pertumbuhan bahan baku mamin untuk industri. Sementara itu, sejalan dengan masih lemahnya investasi swasta hingga triwulan II 2016, impor barang modal masih melanjutkan kontraksi pada Juni 2016 meski membaik dari bulan sebelumnya. 
Dari sisi sektoral, perbaikan ekonomi ditopang oleh sektor jasa keuangan dan pertanian. Jasa keuangan meningkat didorong melebarnya Net Interest Margin (NIM) akibat spread suku bunga kredit dan suku bunga deposito yang meningkat. Dengan kecenderungan Beban Operasional Pendapatan Operasional (BOPO) yang relatif stabil, peningkatan NIM tersebut mendorong peningkatan kinerja sektor jasa keuangan. Selain sektor jasa keuangan, sektor pertanian menjadi sektor pendorong ekonomi domestik. Perbaikan sektor pertanian terutama didorong oleh kenaikan pertumbuhan subsektor tanaman pangan akibat bergesernya panen raya ke triwulan II 2016 sejak tahun 2015.

Secara spasial, pertumbuhan ekonomi pada triwulan II 2016 didorong oleh peningkatan pertumbuhan di wilayah Jawa dan Sumatera, sementara pertumbuhan ekonomi di wilayah Kalimantan dan KTI masih melemah (Gambar 1). Akselerasi di Sumatera didorong peningkatan kinerja sektor pertanian, sektor perdagangan, hotel dan restoran (PHR), serta sektor bangunan. Sementara itu, akselerasi pertumbuhan ekonomi di wilayah Jawa bersumber dari meningkatnya kinerja jasa keuangan dan bangunan. Di sisi lain, pertumbuhan ekonomi di wilayah Kalimantan dan KTI melambat dengan kontraksi yang cukup dalam terjadi di Kalimantan Timur dan Papua. Perlambatan ekonomi di wilayah KTI dipengaruhi oleh masih terkontraksinya pertambangan, sementara perlambatan ekonomi di wilayah Kalimantan dipengaruhi oleh melambatnya seluruh sektor ekonomi, kecuali jasa keuangan.
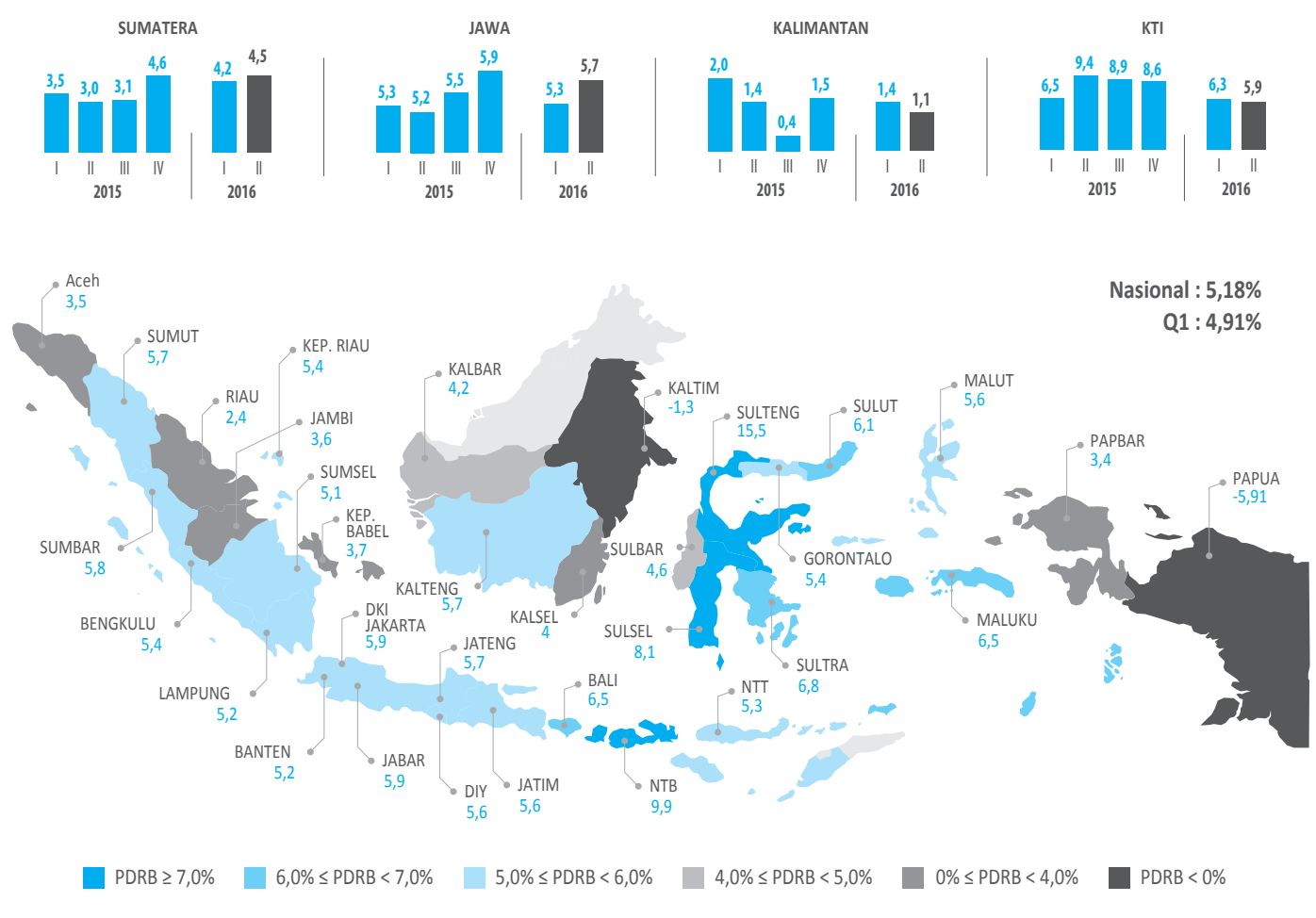

Gambar 1. Peta Pertumbuhan Ekonomi Daerah Triwulan II 2016 


\subsection{Neraca Pembayaran Indonesia}

Defisit transaksi berjalan pada triwulan II 2016 menurun, didorong oleh kenaikan surplus neraca perdagangan nonmigas. Defisit transaksi berjalan menurun dari 4,8 miliar dolar AS (2,2\% PDB) pada triwulan I 2016 menjadi 4,7 miliar dolar AS (2,0\% PDB) pada triwulan II 2016 (Grafik 8). Penurunan tersebut ditopang oleh kenaikan surplus neraca perdagangan nonmigas akibat peningkatan ekspor nonmigas yang lebih besar dari peningkatan impor nonmigas. Kinerja ekspor nonmigas terutama didukung oleh peningkatan ekspor produk manufaktur, seperti tekstil dan produk tekstil, kendaraan dan bagiannya, serta mesin dan peralatan mekanik. Sementara itu, peningkatan impor nonmigas terutama didukung oleh kenaikan impor bahan baku. Di sisi lain, defisit neraca perdagangan migas melebar, seiring dengan meningkatnya harga minyak dunia. Selain itu, defisit neraca jasa juga meningkat mengikuti pola musiman surplus neraca jasa perjalanan yang rendah pada triwulan laporan.

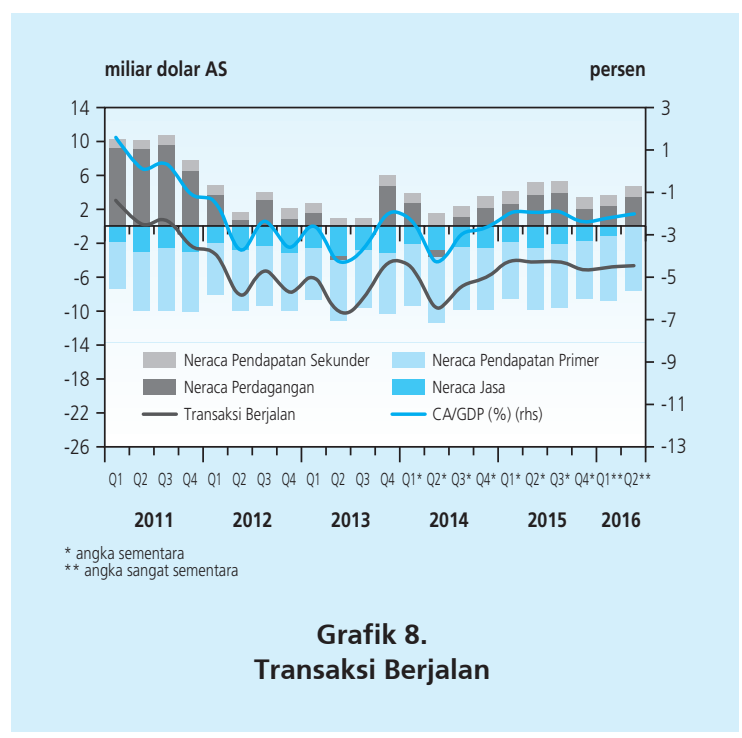

Sementara itu, surplus transaksi modal dan finansial meningkat, didukung oleh persepsi positif investor terhadap prospek perekonomian domestik dan meredanya ketidakpastian di pasar keuangan global. Surplus transaksi modal dan finansial pada triwulan II 2016 mencapai 7,4 miliar dolar AS, lebih besar dibandingkan dengan surplus pada triwulan sebelumnya sebesar 4,6 miliar dolar AS, terutama ditopang oleh aliran masuk modal investasi portofolio. Aliran masuk modal investasi portofolio neto meningkat signifikan mencapai 8,4 miliar dolar AS pada triwulan II 2016, sebagian besar didukung oleh penerbitan obligasi global pemerintah dan net inflows dari investor asing yang melakukan pembelian di pasar saham serta pasar SBN rupiah. Selain itu, surplus investasi langsung juga tercatat meningkat menjadi 3,0 miliar dolar AS dari 2,7 miliar dolar AS pada triwulan I 2016, seiring dengan positifnya prospek ekonomi domestik. 
Secara keseluruhan, Neraca Pembayaran Indonesia (NPI) triwulan II 2016 mencatat surplus, ditopang oleh menurunnya defisit transaksi berjalan dan meningkatnya surplus transaksi modal dan finansial. Surplus NPI tercatat sebesar 2,2 miliar dolar AS, setelah pada triwulan sebelumnya mengalami defisit sebesar 0,3 miliar dolar AS (Grafik 9). Perkembangan ini menunjukkan keseimbangan eksternal perekonomian yang semakin baik dan turut menopang terjaganya stabilitas makroekonomi.

Perkembangan NPI tersebut pada gilirannya memperkuat cadangan devisa. Posisi cadangan devisa meningkat dari 107,5 miliar dolar AS pada akhir triwulan I 2016 menjadi 109,8 miliar dolar AS pada akhir triwulan II 2016 (Grafik 10). Jumlah cadangan devisa tersebut cukup untuk membiayai kebutuhan pembayaran impor dan utang luar negeri pemerintah selama 8,0 bulan dan berada di atas standar kecukupan internasional.

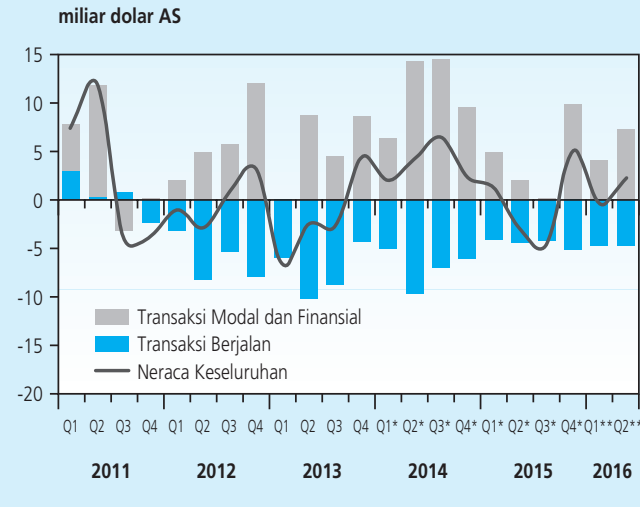

Grafik 9.

Neraca Pembayaran Indonesia

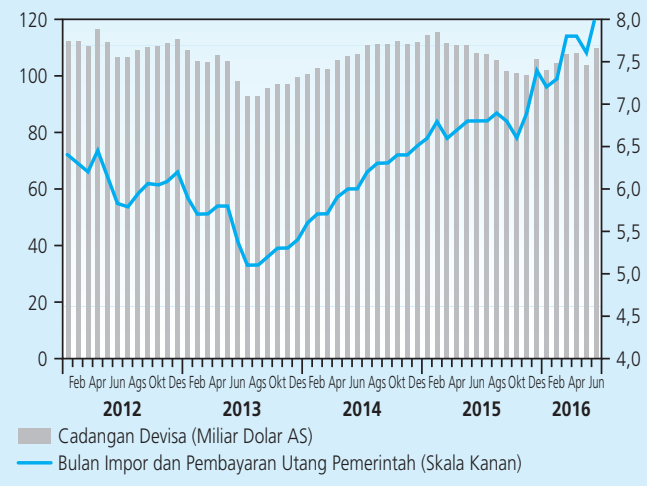

Grafik 10.

Perkembangan Cadangan Devisa

\subsection{Nilai Tukar Rupiah}

Stabilitas nilai tukar rupiah tetap terjaga. Selama triwulan I 2016 nilai tukar rupiah, secara point to point (ptp), menguat sebesar 3,96\% dan mencapai level Rp13.260 per dolar AS (Grafik 11). Penguatan rupiah pada triwulan I 2016 didorong oleh berlanjutnya arus masuk modal asing sejalan dengan optimisme terhadap prospek perekonomian domestik dan terjaganya faktor risiko eksternal. Penguatan rupiah pada triwulan I 2016 didorong oleh faktor domestik dan eksternal. Dari sisi domestik, berlanjutnya penguatan rupiah didukung oleh persepsi positif terhadap perekonomian domestik akibat terjaganya stabilitas makroekonomi dan optimisme terhadap pertumbuhan ekonomi ke depan. Hal tersebut sejalan dengan penurunan BI Rate dan paket kebijakan pemerintah untuk memperbaiki iklim investasi, serta percepatan implementasi proyek-proyek infrastruktur. Selain itu, penguatan rupiah juga ditopang oleh pasokan valas 
korporasi domestik yang berorientasi ekspor. Dari sisi eksternal, penguatan rupiah didorong oleh meredanya risiko di pasar keuangan global terkait kenaikan FFR dan berlanjutnya pelonggaran kebijakan moneter di beberapa negara maju. Pergerakan rupiah disertai dengan volatilitas yang terjaga. Pada triwulan I 2016, volatilitas nilai tukar rupiah mencatat penurunan dan relatif lebih rendah dibandingkan beberapa negara peers. Hal ini sejalan dengan penguatan nilai tukar rupiah yang terjadi secara gradual sejak Februari 2016 (Grafik 12).

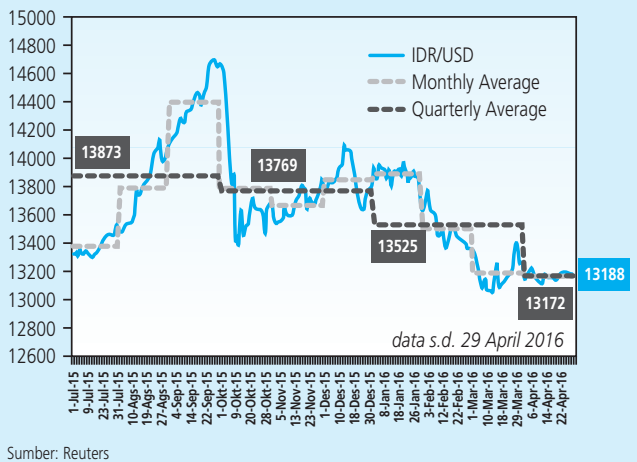

Grafik 11. Nilai Tukar Rupiah

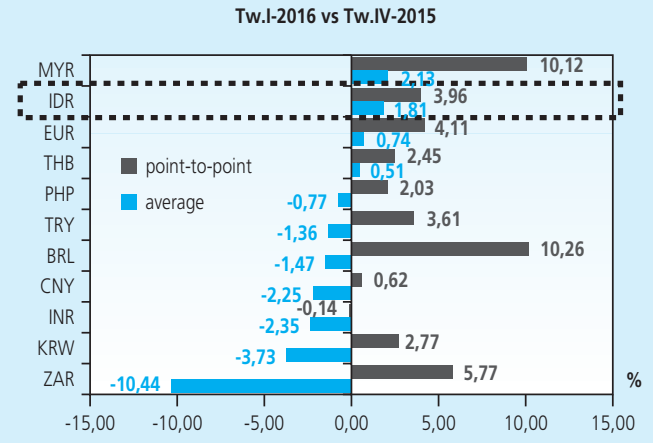

Sumber: Reuters, Bloomberg, diolah

Grafik 12.

Nilai Tukar Kawasan Triwulanan

\subsection{Inflasi}

Inflasi tetap terkendali dalam kisaran sasaran inflasi 2016, yaitu 4ะ1\%. Pada triwulan II 2016, Indeks Harga Konsumen (IHK) mencatat inflasi sebesar 0,44\% (qtq) atau 3,45\% (yoy) lebih rendah dibandingkan dengan triwulan sebelumnya yang sebesar 0,62\% (qtq) atau 4,45\% (yoy). Lebih rendahnya inflasi IHK triwulan II 2016 bersumber dari kelompok volatile foods (VF) dan kelompok inti (Grafik 13).

Inflasi inti tercatat cukup rendah. Secara triwulanan, inflasi inti pada triwulan II 2016 tercatat sebesar 0,72\% (qtq), lebih rendah dibandingkan inflasi inti pada triwulan sebelumnya sebesar $0,80 \%$ (qtq). Rendahnya inflasi inti tersebut sejalan dengan masih terbatasnya permintaan domestik, menguatnya nilai tukar rupiah, serta terkendalinya ekspektasi inflasi. Selain itu, harga komoditas global cenderung lebih rendah dibandingkan triwulan sebelumnya, terutama CPO dan jagung. Sumber tekanan inflasi inti pada triwulan II adalah gula pasir dan emas perhiasan.

Ekspektasi inflasi di tingkat pedagang eceran dan konsumen masih menunjukkan tren yang menurun. Dalam 3 bulan ke depan, ekspektasi inflasi di tingkat konsumen dan pedagang 
eceran menunjukkan penurunan seiring dengan melambatnya permintaan paska Idul Fitri. Penurunan juga terjadi pada ekspektasi inflasi 6 bulan yang akan datang di tingkat pedagang eceran. Namun demikian, ekspektasi inflasi 6 bulan yang akan datang mengalami peningkatan di tingkat konsumen, seiring dengan faktor musiman seperti natal dan liburan akhir tahun (Grafik 14 dan 15).

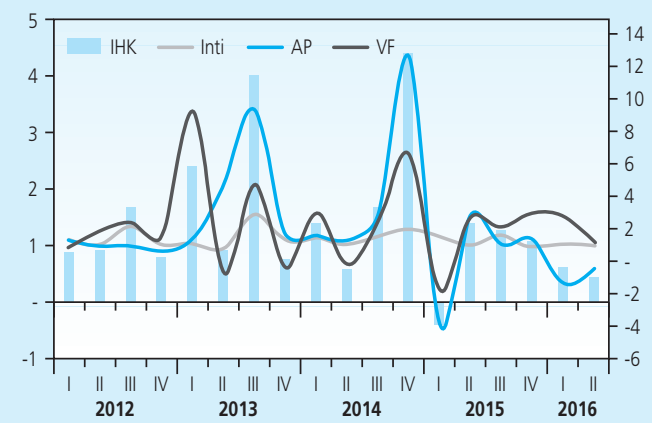

Grafik 13.

Perkembangan Inflasi

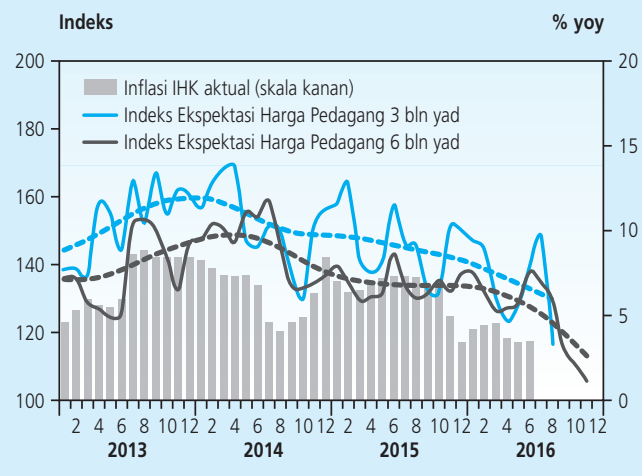

Grafik 14.

Ekspektasi Inflasi Pedagang Eceran

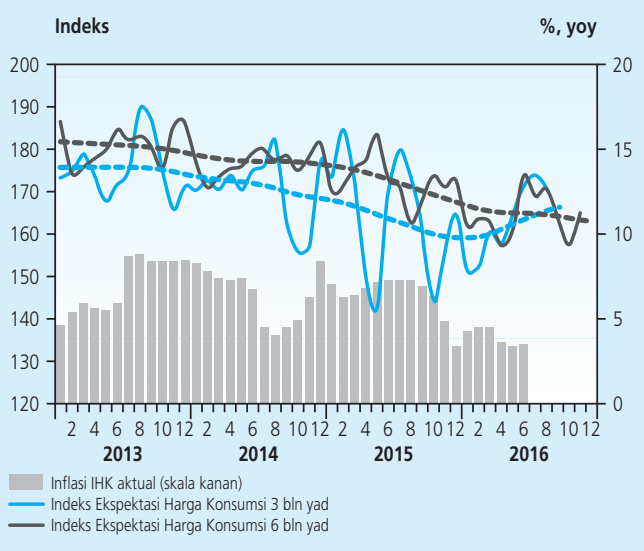

Grafik 15.

Ekspektasi Inflasi Konsumen

Inflasi kelompok volatile foods terjaga. Secara triwulanan, kelompok volatile foods mencatat inflasi sebesar 0,98\% (qtq) atau 8,12\% (yoy), lebih rendah dari inflasi volatile foods pada triwulan I 2016 sebesar 2,47\% (qtq) atau 9,15\% (yoy). Lebih rendahnya inflasi volatile 
foods pada triwulan II 2016 didorong oleh adanya panen raya beras dan panen hortikultura selama periode triwulan II 2016. Inflasi kelompok ini terutama bersumber dari peningkatan komoditas daging ayam ras, wortel, telur ayam ras, minyak goreng, bawang putih dan daging sapi. Peningkatan inflasi volatile foods lebih lanjut mampu ditahan oleh deflasi komoditas beras, seiring dengan panen raya dan deflasi komoditas hortikultura (cabai merah, cabai rawit dan bawang merah), seiring dengan panen komoditas tersebut.

Secara triwulanan, kelompok administered prices (AP) pada triwulan II 2016 mencatat deflasi yang lebih rendah. Kelompok administered prices pada triwulan II 2016 mencatat deflasi sebesar 0,73\% (qtq), lebih rendah dibandingkan deflasi triwulan sebelumnya 1,64\% (qtq). Lebih rendahnya deflasi komponen administered prices terutama didorong oleh kenaikan tarif angkutan udara dan tarif angkutan antar kota, seiring dengan tingginya permintaan menjelang Idul Fitri. Inflasi kelompok AP tertahan oleh kecenderungan penurunan harga bensin, tarif listrik, dan angkutan dalam kota. Penurunan harga tersebut didorong oleh kebijakan pemerintah yang menurunkan harga BBM umum jenis Pertamax, Pertamax Plus, Pertamina Dex dan Pertalite pada pertengahan Mei 2016 dengan rata-rata penurunan sebesar Rp200 per liter.

\section{PERKEMBANGAN MONETER, PERBANKAN, DAN SISTEM PEMBAYARAN}

\subsection{Moneter}

Stance kebijakan moneter yang longgar berlanjut, diikuti oleh penurunan suku bunga di pasar uang. Stance pelonggaran moneter masih berlanjut hingga triwulan II 2016 yang dicerminkan oleh turunnya BI Rate Juni 2016 sebesar 25 bps menjadi 6,50\% diikuti penurunan suku bunga Deposit Facility (DF) menjadi 4,50\% dan Lending Facility (LF) menjadi 7,00\%. Penurunan tersebut kemudian diikuti oleh suku bunga PUAB baik pada tenor O/N maupun tenor lebih panjang.

Kondisi likuiditas di pasar uang tetap terjaga. Suku bunga PUAB O/N mengalami penurunan dari 5,26\% pada triwulan I 2016 menjadi 4,88\% pada triwulan II. Selain di tenor $\mathrm{O} / \mathrm{N}$, penurunan juga terjadi pada tenor yang lebih panjang, sejalan dengan tekanan kebutuhan likuiditas yang menurun. Pada triwulan II 2016, kondisi likuiditas di pasar uang tetap terjaga. Hal ini tercermin dari volume rata-rata PUAB O/N naik menjadi Rp8,06 triliun dari sebelumnya Rp7,11 triliun. Di sisi lain, rata-rata spread suku bunga max - min PUAB O/N meningkat dari 15 bps pada triwulan I 2016 menjadi 23 bps pada triwulan II 2016. Peningkatan ini disebabkan shock temporer pada akhir Juni 2016 seiring pola seasonal Ramadhan. Namun, kondisi tersebut kembali normal pasca libur Lebaran, seiring dengan kembali masuknya uang kartal ke perbankan.

Suku bunga deposito perbankan turun, merespon stance pelonggaran kebijakan moneter. Dibandingkan triwulan I 2016, rata-rata tertimbang (RRT) suku bunga deposito pada triwulan II 2016 turun sebesar 43 bps menjadi 7,14\%. Dengan demikian, secara year to date (ytd), RRT suku bunga deposito pada triwulan II 2016 telah turun sebesar 80 bps. Penurunan suku bunga deposito terjadi pada tenor 1 sampai dengan 12 bulan. Penurunan terbesar terjadi pada tenor 
pendek 3 bulan yang turun sebesar 75 bps (qtq) menjadi 7,00\% diikuti tenor 6 bulan yang turun sebesar 56 bps (qtq) menjadi 7,75\%. Sementara itu, tenor panjang 24 bulan tercatat naik sebesar 4 bps menjadi 9,16\%. Pergerakan suku bunga deposito jangka panjang cenderung lebih kaku karena tenor jatuh temponya yang relatif lebih panjang, sehingga respon terhadap penurunan suku bunga menjadi lebih lambat.

Suku bunga kredit perbankan pada triwulan II 2016 tercatat menurun dibanding triwulan sebelumnya. Dibandingkan triwulan I 2016, RRT suku bunga kredit pada triwulan II 2016 turun sebesar 32 bps menjadi 12,38\% searah dengan penurunan BI Rate dan suku bunga deposito. Secara year to date (ytd), RRT suku bunga kredit pada triwulan II 2016 turun sebesar 45 bps, lebih lambat dibandingkan penurunan RRT suku bunga deposito. Penurunan suku bunga kredit terjadi pada seluruh jenis kredit, dengan penurunan suku bunga terbesar terjadi pada jenis kredit modal kerja (KMK) yang turun 46 bps menjadi 11,82\% (Grafik 16). Lebih lambatnya penurunan RRT suku bunga kredit ditengah stance pelonggaran kebijakan moneter dipengaruhi oleh meningkatnya faktor risiko kredit (NPL). Spread antara suku bunga deposito dan suku bunga kredit pada triwulan II 2016 semakin melebar menjadi 524 bps dari triwulan sebelumnya 513 bps (Grafik 17).

Pertumbuhan likuiditas perekonomian (M2) meningkat. Pada triwulan II 2016, M2 tercatat tumbuh sebesar 8,7\% (yoy), meningkat dari pertumbuhan pada triwulan sebelumnya sebesar 7,4\% (yoy). Peningkatan pertumbuhan M2 tersebut didorong oleh baik uang kuasi maupun M1. Peningkatan pertumbuhan uang kuasi terutama didorong oleh deposito Rupiah dan tabungan Rupiah. Pertumbuhan M1 pada triwulan II 2016 tercatat sebesar 13,94\% (yoy), meningkat dibandingkan triwulan I 2016 sebesar 11,18\% (yoy). Meningkatnya pertumbuhan

$\%$

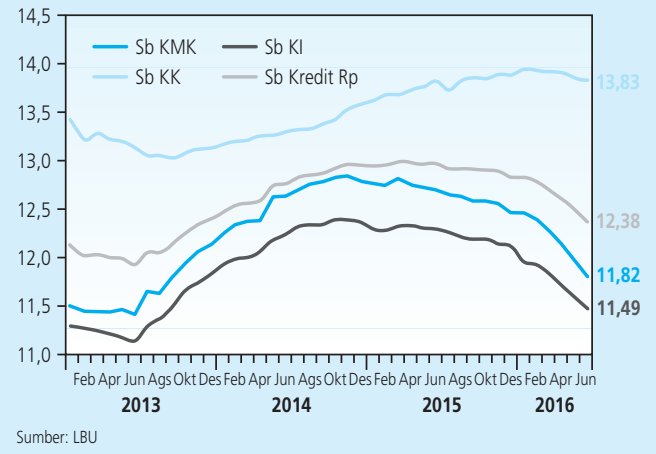

Grafik 16.

Suku Bunga Kredit: KMK, KI dan KK

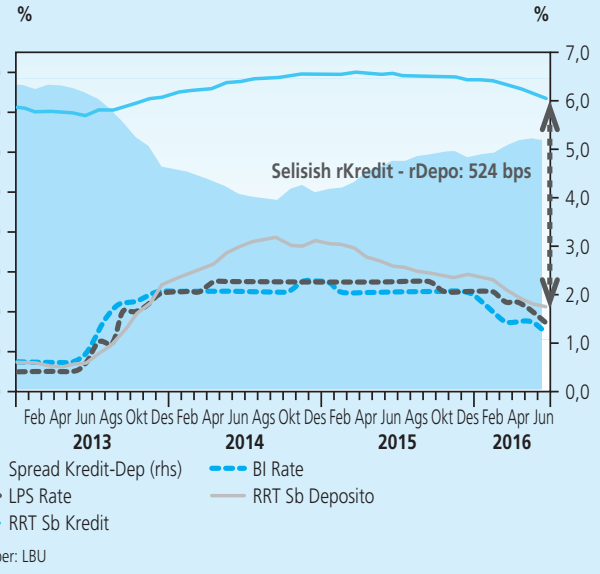

Grafik 17

Spread Suku Bunga Perbankan 
M1 pada triwulan II 2016 tersebut didorong oleh meningkatnya pertumbuhan uang kartal (currency outside bank) yang dipengaruhi oleh faktor musiman hari raya lebaran.

\subsection{Industri Perbankan}

Stabilitas sistem keuangan (SSK) tetap stabil dan ditopang oleh ketahanan sistem perbankan yang terjaga. Kondisi SSK tersebut didukung oleh likuiditas perbankan yang memadai dan permodalan perbankan yang kuat. Kondisi SSK ke depan masih terus dijaga agar dapat tetap mendukung proses intermediasi yang diharapkan dapat tumbuh lebih tinggi.

Laju pertumbuhan kredit pada triwulan II 2016 masih terbatas. Pertumbuhan kredit tercatat sebesar 8,9\% (yoy), meningkat dari pertumbuhan triwulan sebelumnya sebesar 8,7\% (yoy). Pertumbuhan kredit pada triwulan II 2016 didorong oleh peningkatan kredit konsumsi (KK). Sementara itu, kredit investasi (KI) dan kredit modal kerja (KMK) tercatat masih mengalami perlambatan, meskipun pada akhir triwulan II 2016 KMK mulai menunjukkan pertumbuhan positif (Grafik 18). Secara sektoral, kredit triwulan II 2016 di seluruh sektor tumbuh positif kecuali sektor pertambangan seiring dengan masih lemahnya permintaan kredit di sektor tersebut.

Pertumbuhan Dana Pihak Ketiga (DPK) pada triwulan II 2016 tercatat sebesar 5,9\% (yoy), melambat dibandingkan dengan pertumbuhan triwulan sebelumnya sebesar 6,5\% (yoy) (Grafik 19). Perlambatan pertumbuhan DPK pada triwulan II 2016 terutama bersumber dari perlambatan pertumbuhan deposito dan giro. Perlambatan pertumbuhan deposito, antara lain terkait dengan pengalihan ke instrumen keuangan lainnya, sementara penurunan pertumbuhan giro terkait dengan perilaku keuangan pemerintah dan pembayaran THR. Sementara itu, tabungan meningkat signifikan mencapai 16,3\% sehingga meningkatkan rasio current account, saving account (CASA) menjadi 54,5\%.

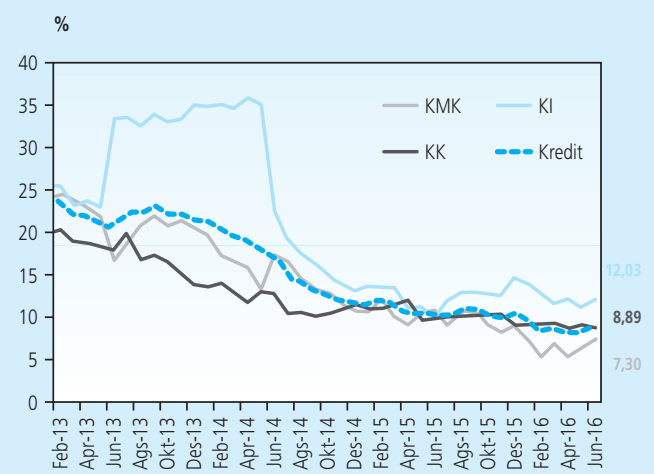

Grafik 18.

Pertumbuhan Kredit Menurut Penggunaan

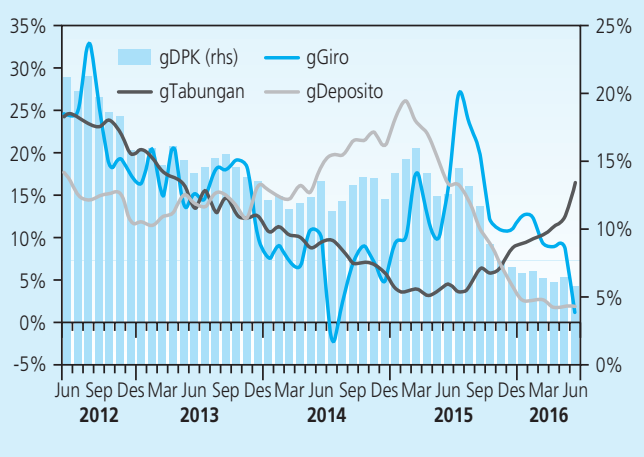

Grafik 19. Pertumbuhan DPK 
Kondisi perbankan masih cukup terjaga di tengah pertumbuhan kredit yang masih terbatas. Pada akhir triwulan II 2016, ketahanan permodalan masih memadai dengan rasio kecukupan modal (Capital Adequacy Ratio/CAR) tercatat sebesar 22,3\%, jauh di atas ketentuan minimum 8\% (Tabel 2). Sejalan dengan perlambatan kredit, risiko kredit (NPL) pada triwulan II 2016 berada di kisaran 3,1\% (gross) atau 1,5\% (net). Dari sisi likuiditas, likuiditas perbankan pada triwulan II 2016 cukup memadai, seperti tercermin pada rasio Alat Likuid terhadap Dana Pihak Ketiga (AL/DPK) yang berada pada level 20,3\%.

\begin{tabular}{|c|c|c|c|c|c|c|c|c|}
\hline \multicolumn{9}{|c|}{$\begin{array}{c}\text { Tabel } 2 \\
\text { Kondisi Umum Perbankan }\end{array}$} \\
\hline \multirow{2}{*}{ Indikator Utama } & & \multirow{2}{*}{$\begin{array}{c}2015 \\
\text { Des }\end{array}$} & \multicolumn{6}{|c|}{2016} \\
\hline & & & Jan & Feb & Mar & Apr & Mei & Jun \\
\hline Total Aset & (T Rp) & $6.132,83$ & $6.095,91$ & $6.119,35$ & $6.167,75$ & $6.180,70$ & $6.243,11$ & $6.362,70$ \\
\hline DPK & (T Rp) & $4.413,24$ & $4.385,02$ & $4.437,51$ & $4.468,95$ & $4.478,41$ & $4.508,45$ & $4.574,67$ \\
\hline Kredit* & (T Rp) & $4.058,13$ & $3.983,04$ & $3.967,91$ & $4.000,45$ & $4.006,71$ & $4.070,45$ & $4.168,31$ \\
\hline LDR $^{*}$ & $(\%)$ & 91,95 & 90,83 & 89,42 & 89,52 & 89,47 & 90,28 & 91,12 \\
\hline NPLsBruto* & $(\%)$ & 2,49 & 2,73 & 2,87 & 2,83 & 2,93 & 3,11 & 3,05 \\
\hline CAR & $(\%)$ & 21,16 & 21,52 & 21,69 & 21,76 & 21,73 & 22,15 & 22,30 \\
\hline NIM & (\%) & 5,23 & 5,49 & 5,32 & 5,40 & 5,41 & 5,42 & 5,42 \\
\hline ROA & (\%) & 2,26 & 2,46 & 2,24 & 2,38 & 2,33 & 2,27 & 2,24 \\
\hline
\end{tabular}

\subsection{Pasar Saham dan Pasar Surat Berharga Negara}

Pasar saham domestik selama triwulan II 2016 menunjukkan kinerja yang terus membaik, antara lain didorong oleh berbagai faktor positif domestik dan global. Kinerja IHSG triwulan II 2016 mencapai level 5.016,65 (30 Juni 2016), naik sebesar 3,5\% (qtq) (Grafik 20). Dari sisi domestik, membaiknya IHSG didorong oleh persepsi positif terkait terjaganya stabilitas makro dan pengesahan UU Pengampunan Pajak. Dari sisi global, perbaikan IHSG ditopang oleh sentimen positif terkait dengan terbatasnya dampak Brexit dan perkiraan penundaan kenaikan FFR. Kinerja pergerakan IHSG juga masih lebih baik dibandingkan bursa saham kawasan (Malaysia, Singapura dan Thailand). Pertumbuhan IHSG berada di atas Malaysia $(-3,7 \%)$, Singapura $(0,0 \%)$, dan Thailand (2,6\%).

Sejalan dengan pasar saham, pasar SBN menunjukkan kinerja yang positif. Membaiknya kondisi pasar SBN ditandai oleh yield SBN yang turun di seluruh tenor. Secara keseluruhan, yield turun sebesar 27bps menjadi 7,46\% pada triwulan II 2016 dari 7,73\% pada triwulan I 2016. Adapun yield jangka pendek, menengah dan panjang masing-masing turun sebesar 25 bps, 24 bps dan 39 bps menjadi 7,12\%, 7,47\% dan 7,89\%. Sementara itu, yield benchmark 10 tahun turun sebesar 22 bps menjadi 7,45\% dari 7,67. Perbaikan tersebut didorong oleh faktor positif global dan domestik, yang relatif sama dengan faktor positif yang mendorong perbaikan IHSG. Di tengah penurunan yield SBN, investor nonresiden mencatatkan net beli 


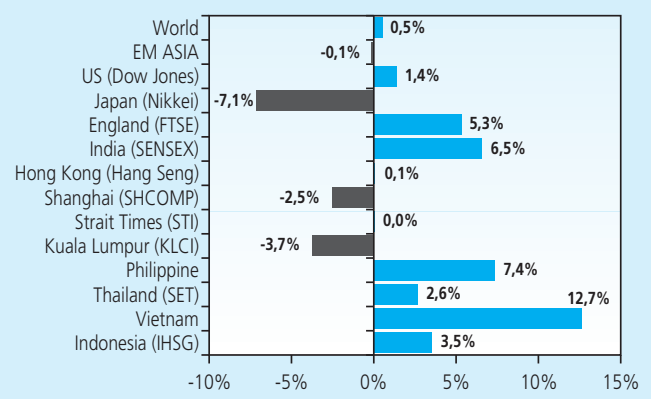

Grafik 20. IHSG dan Indeks Bursa Global Triwulan II 2016 (qtq)

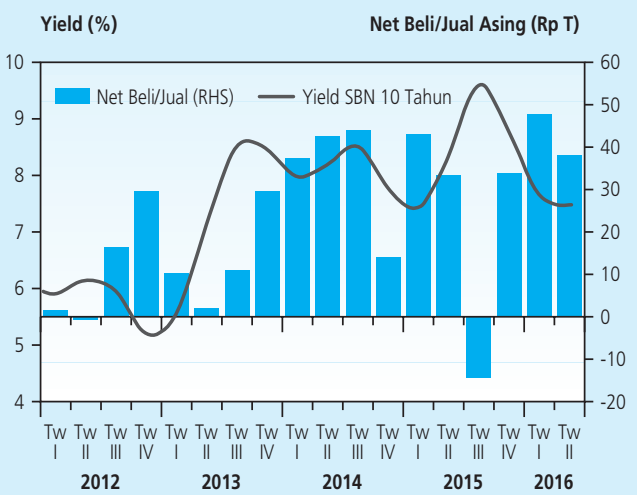

Grafik 21. Yield SBN dan Net Jual/Beli Asing Triwulanan

sebesar Rp37,90 triliun pada triwulan II 2016, menurun dibandingkan triwulan sebelumnya yang sebesar Rp47,53 triliun (Grafik 21).

\subsection{Pembiayaan Non Bank}

Pembiayaan ekonomi nonbank meningkat cukup signifikan. Total pembiayaan selama triwulan Il 2016 melalui penerbitan saham perdana, right issue, obligasi korporasi, medium term notes, promissory notes dan lembaga keuangan lainnya meningkat menjadi Rp83,1 triliun dari Rp24,2 triliun pada triwulan I 2016 (Tabel 3). Peningkatan tersebut terutama didorong oleh meningkatnya penerbitan saham dan penerbitan obligasi. Peningkatan pembiayaan nonbank tersebut merupakan alternatif pembiayaan bagi sektor swasta di tengah masih terbatasnya pembiayaan kredit perbankan.

\begin{tabular}{|c|c|c|c|c|c|c|c|c|c|c|c|c|c|c|}
\hline \multicolumn{15}{|c|}{$\begin{array}{c}\text { Tabel } 3 \\
\text { Pembiayaan Non Bank }\end{array}$} \\
\hline \multirow{2}{*}{ Indikator Utama } & \multicolumn{5}{|c|}{2015} & \multicolumn{9}{|c|}{2016} \\
\hline & Tw I & Tw II & Tw III & Tw IV & Total & Jan & Feb & Mar & Apr & Mei & Jun & Tw I & Tw II & YTD \\
\hline Nonbank & 22,3 & 47,7 & 17,6 & 41,6 & 129,2 & 6,0 & 12,3 & 6,0 & 3,5 & 36,4 & 43,4 & 24,2 & 83,1 & 107,3 \\
\hline Saham & 4,7 & 14,5 & 5,3 & 29,1 & 53,6 & 0,3 & 0,1 & 0,4 & 0,4 & 19,4 & 21,0 & 0,8 & 40,8 & 41,6 \\
\hline o/w Emiten Sektor Keuangan & 0,0 & 0,0 & 0,1 & 0,0 & 0,1 & 0,0 & 0,0 & 0,0 & 0,4 & 6,2 & 3,5 & 0,0 & 10,1 & 10,2 \\
\hline Obligasi & 12,8 & 26,1 & 9,5 & 6,9 & 55,3 & 5,4 & 8,1 & 4,4 & 0,7 & 16,1 & 16,5 & 17,8 & 33,2 & 51,0 \\
\hline o/w Emiten Sektor Keuangan & 12,1 & 9,9 & 7,5 & 5,6 & 35,1 & 5,4 & 8,1 & 4,4 & 0,2 & 16,1 & 9,1 & 17,8 & 25,3 & 43,1 \\
\hline MTN dan Promissory Notes + NCD & 4,8 & 7,0 & 2,8 & 5,5 & 20,1 & 0,3 & 4,1 & 1,2 & 2,4 & 0,9 & 5,9 & 5,6 & 9,1 & 14,7 \\
\hline o/w Emiten Sektor Keuangan & 3,3 & 6,3 & 1,2 & 3,4 & 14,2 & 0,0 & 3,9 & 0,7 & 1,9 & 0,0 & 5,7 & 4,5 & 7,6 & 12,1 \\
\hline
\end{tabular}




\subsection{Perkembangan Sistem Pembayaran}

Perkembangan pengelolaan uang rupiah secara umum sejalan dengan perkembangan ekonomi domestik, khususnya dari sektor konsumsi rumah tangga. Posisi Uang Kartal yang Diedarkan (UYD) pada akhir triwulan II 2016 tercatat sebesar Rp642,0 triliun, tumbuh 26,7\% (yoy), atau $26,2 \%$ (qtq) (Grafik 22). Peningkatan UYD tersebut menunjukkan masih tingginya peran uang tunai sebagai alat pembayaran dalam kegiatan ekonomi nasional, khususnya konsumsi rumah tangga. Konsumsi rumah tangga tumbuh meningkat didukung oleh dampak kebijakan moneter yang akomodatif. Di samping itu, peningkatan konsumsi Pemerintah sebagai dampak ekspansi fiskal pemerintah selama triwulan II 2016 juga menjadi salah satu faktor meningkatnya pertumbuhan UYD pada triwulan II 2016.

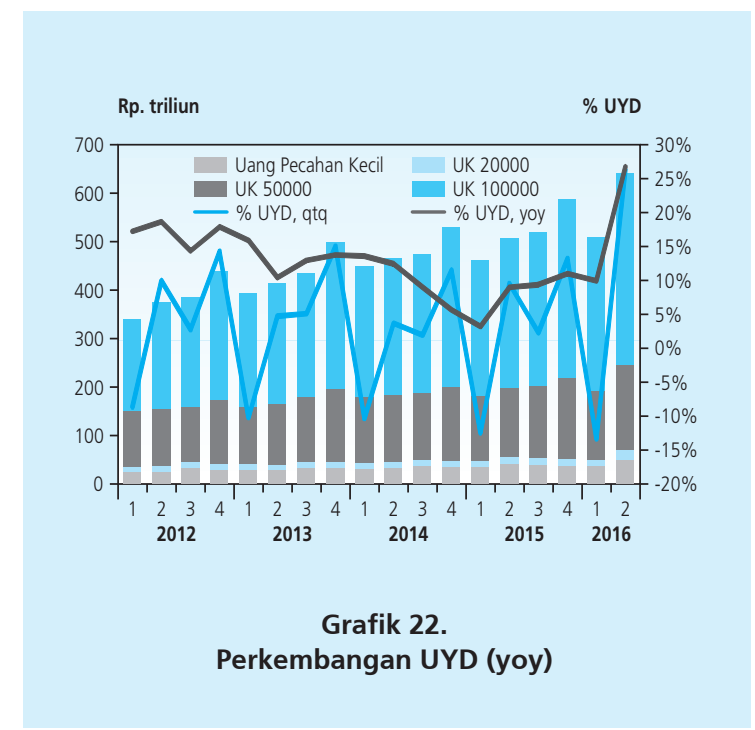

Bank Indonesia berkomitmen untuk menyediakan uang layak edar bagi masyarakat, yaitu uang Rupiah asli yang memenuhi persyaratan untuk diedarkan berdasarkan standar kualitas yang ditetapkan oleh Bank Indonesia. Selama triwulan II 2016, Bank Indonesia memusnahkan Uang Tidak Layak Edar (UTLE) dalam berbagai denominasi khususnya uang Rupiah kertas sebanyak 1,4 miliar lembar atau senilai Rp49,9 triliun. Jumlah pemusnahan UTLE tersebut lebih tinggi dibandingkan dengan periode yang sama tahun sebelumnya yang tercatat sebesar 1,2 miliar lembar atau senilai Rp33,4 triliun. Peningkatan jumlah lembar dan nominal pemusnahan UTLE tersebut merupakan konsekuensi dari penetapan standar kualitas uang yang lebih tinggi.

Penyelenggaraan sistem pembayaran selama triwulan II 2016 berjalan aman, lancar, dan terpelihara dengan baik. Kondisi tersebut seiring dengan pembaruan Sistem Bank Indonesia Real Time Gross Settlement (Sistem BI-RTGS), Bank Indonesia - Scripless Securities Settlement 
System (BI-SSSS) Generasi II serta Sistem Kliring Nasional Bank Indonesia (SKNBI) Generasi II. Volume transaksi sistem pembayaran yang diselenggarakan oleh BI tercatat sebesar 33.875,40 ribu transaksi atau naik 9,71\% dibandingkan triwulan sebelumnya yang sebanyak 30.877,25 ribu transaksi. Kenaikan volume transaksi tersebut terjadi pada seluruh sistem pembayaran yang diselenggarakan oleh BI meliputi BI-RTGS, SI-SSSS maupun SKNBI, yang masing-masing meningkat sebesar $6,10 \%$ (qtq), 16,76\% (qtq), dan 9,87\% (qtq) (Tabel 4). Sementara itu, nilai transaksi mengalami penurunan sebesar 1,84\% (qtq) dari Rp40.844,77 triliun menjadi Rp40.094,25 triliun (Tabel 5). Penurunan nilai transaksi tersebut didorong oleh menurunnya nilai transaksi BI-SSSS sebesar 9,37\% (qtq) atau turun Rp1.217,76 triliun.

Selama triwulan II 2016, transaksi pada sistem BI-RTGS mengalami peningkatan, baik dari sisi volume maupun nilai dibandingkan dengan triwulan sebelumnya. Volume transaksi sistem pembayaran yang diselesaikan melalui sistem BI-RTGS tercatat meningkat sebesar 6,10\% (qtq) dari 1.436,25 ribu transaksi menjadi 1.523,86 ribu transaksi. Peningkatan volume tersebut sejalan dengan peningkatan nilai transaksi sebesar 1,41\% (qtq) menjadi Rp27.117,76 triliun pada triwulan II 2016. Secara umum, peningkatan volume dan nilai transaksi BI-RTGS terutama bersumber dari kenaikan transfer dana masyarakat (antar nasabah) baik dari sisi volume maupun nilai transaksi, masing-masing sebesar 7.26\% (qtq) dan 13.67\% (qtq).

Peningkatan nilai transaksi SKNBI didorong oleh meningkatnya transaksi kliring kredit/ transfer dana. Hal ini merupakan dampak dari implementasi kebijakan batas atas nominal transfer dana SKNBI serta batas bawah nominal transfer dana melalui Sistem BI-RTGS². Melalui adanya kebijakan tersebut, volume transaksi melalaui SKNBI tercatat meningkat 9,87\% (qtq) menjadi 32.271,09 ribu transaksi pada triwulan II 2016. Sejalan dengan peningkatan volume, nilai transaksi melalui SKNBI juga mengalami peningkatan sebesar 8,02\% (qtq) dibandingkan triwulan sebelumnya.

Sementara itu, transaksi Alat Pembayaran dengan Menggunakan Kartu (APMK) pada triwulan II-2016 mencatat pertumbuhan positif. Volume transaksi APMK meningkat sebesar 7,31\% menjadi 1.388,41 juta transaksi. Hal tersebut menunjukan semakin seringnya penggunaan APMK di masyarakat, khususnya Kartu ATM dan/atau Kartu Debet. Nilai transaksi pada periode laporan juga mencatat peningkatan sebesar 10,21\%. Kartu ATM/Debet masih mendominasi volume dan nilai transaksi APMK dibandingkan kartu kredit dengan proporsi masing-masing sebesar $94.58 \%$ dan $5.42 \%$ (pangsa volume) serta sebesar $95,37 \%$ dan $4.63 \%$ (pangsa nominal). Peningkatan volume dan nilai transaksi APMK pada triwulan laporan yang cukup tinggi ditengarai merupakan peningkatan siklikal mengingat pada periode laporan terdapat libur hari raya Idul Fitri.

2 Batas nominal transaksi melalui SKNBI yang semula maksimal Rp500 juta menjadi tidak terbatas, adapun batas nominal transfer dana melalui Sistem BI-RTGS yang semula minimal Rp100 juta dinaikkan menjadi Rp500 juta. 
Nilai transaksi uang elektronik mengalami peningkatan. Pada triwulan II 2016, transaksi uang elektronik tumbuh sebesar 26,91\% dibandingkan triwulan sebelumnya menjadi Rp1,78 triliun. Selain itu, tercatat peningkatan volume transaksi sebesar 22,32\% menjadi 169,51 juta transaksi. Rata-rata nilai penggunaan uang elektronik dalam satu transaksi pada periode laporan tercatat sebesar Rp10.473.

\begin{tabular}{|c|c|c|c|c|c|c|c|c|}
\hline \multicolumn{9}{|c|}{$\begin{array}{c}\text { Tabel } 4 \\
\text { Perkembangan Volume Sistem Pembayaran Non Tunai }\end{array}$} \\
\hline \multirow[b]{2}{*}{$\begin{array}{l}\text { Transaksi Sistem } \\
\text { Pembayaran Non Tunai }\end{array}$} & \multicolumn{5}{|c|}{2015} & \multicolumn{3}{|c|}{2016} \\
\hline & Q I & Q II & Q III & Q IV & Total & QI & Q II & $\begin{array}{c}\text { QtQ } \\
\text { (I 2016 to II } \\
\text { 2016) }\end{array}$ \\
\hline BI-RTGS & $2.814,82$ & $2.917,79$ & $2.939,05$ & $2.371,24$ & $11.042,90$ & $1.436,25$ & $1.523,86$ & $6,10 \%$ \\
\hline BI-SSSS & 45,60 & 46,36 & 39,78 & 51,91 & 183,65 & 68,91 & 80,46 & $16,76 \%$ \\
\hline Kliring & $27.120,50$ & $27.868,97$ & $27.855,16$ & $30.688,25$ & $113.532,88$ & $29.372,08$ & $32.271,09$ & $9,87 \%$ \\
\hline APMK & $1.142 .496,20$ & 1.203.569,01 & $1.224 .670,52$ & $1.284 .977,74$ & $4.855 .713,47$ & $1.293 .820,18$ & $1.388 .411,40$ & $7,31 \%$ \\
\hline Kartu Kredit & $65.662,44$ & $70.286,39$ & $71.179,69$ & $74.197,00$ & $281.325,52$ & $74.009,24$ & $75.207,12$ & $1,62 \%$ \\
\hline Kartu ATM dan ATM/Debet & $1.076 .833,76$ & 1.133.282,61 & $1.153 .490,84$ & $1.210 .780,00$ & $4.574 .387,21$ & $1.219 .810,94$ & $1.313 .204,28$ & $7,66 \%$ \\
\hline Uang Elektronik & $80.265,97$ & $143.092,96$ & $172.725,50$ & $139.495,00$ & $535.579,43$ & $138.580,86$ & $169.514,85$ & $22,32 \%$ \\
\hline Total & $1.252 .743,10$ & $1.377 .495,09$ & 1.428.230,01 & $1.457 .584,24$ & $5.516 .052,44$ & $1.463 .278,28$ & $1.591 .801,65$ & $8,78 \%$ \\
\hline
\end{tabular}

\begin{tabular}{|c|c|c|c|c|c|c|c|c|}
\hline \multicolumn{9}{|c|}{$\begin{array}{c}\text { Tabel } 5 \\
\text { Perkembangan Nilai Sistem Pembayaran Non Tunai }\end{array}$} \\
\hline \multirow[b]{2}{*}{$\begin{array}{l}\text { Transaksi Sistem } \\
\text { Pembayaran Non Tunai }\end{array}$} & \multicolumn{5}{|c|}{2015} & \multicolumn{3}{|c|}{2016} \\
\hline & Q I & Q II & Q III & Q IV & Total & QI & Q II & $\begin{array}{c}\text { QtQ } \\
\text { (1 2016 to II } \\
\text { 2016) }\end{array}$ \\
\hline BI-RTGS & $28.879,17$ & $28.089,25$ & $28.022,31$ & $27.736,72$ & $112.727,45$ & $26.739,53$ & $27.117,76$ & $1,41 \%$ \\
\hline BI-SSSS & $8.758,28$ & $7.697,54$ & $8.025,62$ & $10.703,05$ & $35.184,49$ & $12.994,90$ & $11.777,14$ & $-9,37 \%$ \\
\hline Kliring & 732,49 & 743,01 & 739,33 & $1.026,24$ & $3.241,07$ & $1.110,34$ & $1.199,35$ & $8,02 \%$ \\
\hline APMK & $1.207,04$ & $1.281,17$ & $1.320,67$ & $1.369,46$ & $5.178,34$ & $1.368,51$ & $1.508,24$ & $10,21 \%$ \\
\hline Kartu Kredit & 66,02 & 71,15 & 70,55 & 72,83 & 280,55 & 69,86 & 69,84 & $-0,03 \%$ \\
\hline Kartu ATM dan ATM/Debet & $1.141,03$ & $1.210,02$ & $1.250,12$ & $1.296,63$ & $4.897,80$ & $1.298,66$ & $1.438,40$ & $10,76 \%$ \\
\hline Uang Elektronik & 0,84 & 1,44 & 1,67 & 1,34 & 5,29 & 1,40 & 1,78 & $27,14 \%$ \\
\hline Total & $39.577,83$ & $37.812,41$ & $38.109,60$ & $40.836,81$ & $156.336,65$ & $42.214,68$ & $41.604,26$ & $-1,45 \%$ \\
\hline
\end{tabular}




\section{PROSPEK PEREKONOMIAN}

Pertumbuhan ekonomi pada 2016 diperkirakan masih akan terjaga dengan baik, meskipun kisaran proyeksi pertumbuhan 2016 sedikit lebih rendah dibandingkan perkiraan sebelumnya. Terjaganya pertumbuhan ekonomi pada 2016 diperkirakan akan didukung oleh pelonggaran kebijakan moneter dan makropudensial yang telah ditempuh dan percepatan implementasi Paket Kebijakan Pemerintah. Namun demikian, penghematan belanja pemerintah pada semester II 2016 berpotensi menurunkan pertumbuhan tahun ini. Dengan perkembangan tersebut, pertumbuhan ekonomi untuk keseluruhan 2016 diperkirakan akan berada di kisaran 4,9-5,3\% (yoy), sedikit lebih rendah dari kisaran sebelumnya, yaitu 5,0 - 5,4\% (yoy).

Inflasi tahun 2016 diprakirakan berada dalam rentang sasaran inflasi sebesar 4ะ1\%. Di sisi domestik, tekanan inflasi dari sisi permintaan diprakirakan relatif terbatas. Meningkatnya permintaan domestik diprakirakan masih dapat direspons oleh kapasitas produksi. Ekspektasi inflasi diperkirakan juga tetap terjaga dengan dukungan kebijakan dan koordinasi antara Bank Indonesia dan Pemerintah. Di sisi eksternal, tekanan inflasi diprakirakan relatif terjaga. Hal tersebut didukung oleh perkiraan terbatasnya peningkatan harga-harga komoditas internasional, sejalan dengan laju perbaikan perekonomian dunia yang berlangsung secara gradual. Tekanan dari sisi nilai tukar juga diperkirakan terkendali pada tahun 2016. Dalam upaya mencapai sasaran inflasi tersebut, Bank Indonesia akan terus memperkuat koordinasi dengan Pemerintah Pusat dan Pemerintah Daerah, melalui forum TPI dan TPID, guna mengendalikan tekanan inflasi, khususnya inflasi volatile food.

Bank Indonesia akan terus mencermati beberapa risiko perekonomian yang berasal dari eksternal maupun domestik. Dari sisi global, pemulihan ekonomi global masih lemah. Meskipun membaik, ekonomi AS pada triwulan II 2016 tumbuh di bawah perkiraan seiring dengan investasi yang masih melambat. Perkembangan ekonomi AS tersebut masih dibayangi oleh ketidakpastian, sehingga kenaikan Fed Fund Rate (FFR) pada 2016 diperkirakan akan dilakukan hanya satu kali dalam 2016. Dari sisi domestik, risiko yang perlu mendapat perhatian adalah terbatasnya ruang fiskal akibat potensi melambatnya penerimaan pajak. Penerimaan dana hasil Tax Amnesty masih terus berjalan dan diharapkan dapat memberikan kontribusi dalam mengatasi keterbatasan ruang fiskal. Selain itu, perlu diwaspadai pula risiko pertumbuhan ekonomi yang lebih rendah dari perkiraan akibat pengurangan belanja Pemerintah guna menjaga defisit APBN tetap berada dalam tingkat yang sehat. 